\title{
Is There any Differences of Job Stress Among Correctional Officers Based on Gender in Java?
}

\author{
Unika Prihatsanti \\ Faculty of Psychology, Diponegoro University, Indonesia \\ unik0206@gmail.com \\ (Corresponding author) \\ Ika Zenita Ratnaningsih \\ Faculty of Psychology, Diponegoro University, Indonesia \\ Anggun Resdasari Prasetyo \\ Faculty of Psychology, Diponegoro University, Indonesia
}

\begin{abstract}
The purpose of this study is to investigate the differences of job stress based on gender among correctional officers in three prisons in Java Indonesia. This study was a quantitative survey study focused on the comparison between male and female. The data were collected from 95 correctional officers from Bandung and Semarang prisons. The analysis of variance test (ANOVA) was used to test the study hypotheses. The results show that gender variable has influences on job stress, in which female correctional officers have higher job stress level than male correctional officers.
\end{abstract}

Keywords: gender, job stress, correctional officers

\section{Introduction}

A job as a correctional officer is a tough and dangerous one. The job is considered to give even less prestige in the community. The imbalance between workload and ability to complete the work is going on at the prison situation in Indonesia because there is the issue of excess capacity in most prisons in Indonesia. Correctional officers work in long shifts, deal with over-capacity conditions, and are required to establish good relationship to their inmates, superiors and fellow guards. These conditions apply to both male and female correctional officers. Basically, the placement of inmates in prisons in Indonesia is based on the classifications of age, sex, and types of criminal offenses/crimes. The guidance to the inmates becomes one of the tasks of the correctional officers (Sudaryono, 2013).

The current prison conditions in Indonesia have overloaded capacity for housing prisoners. The number of prisoners increased twice between 2004 and 2011, from about 71,500 to 144,000. At the same time, prison capacity increased by less than two per cent. This condition made prisons overcrowded by 45 percent on average, while many Class 1 prisons in the major cities are overcrowded by 400 percent (Sudaryono, 2013). Overloaded and crowded capacity is one reason when there were prisoners who escaped from prison. This condition involves ultimately the responsibility of correctional officers. Excess capacity also 
means work overload for correctional officers in which one of their tasks is to provide guidance to the inmates.

Based on the interviews in the correctional officers in Java, Indonesia, it was found that the job demands were too heavy which was the source of stress coming from the fear of physical threat because the officers have to keep a lot number of prisoners, fears of chaos in some prisons in Indonesia which was quite often the case, and low co-worker support and management in which the lack of personnel make it difficult to coordinate with family roles. This condition affects the correctional officers physically, psychologically and on their daily behavior.

Correctional officers are the subject of fairly susceptible conditions or situations that cause job stress (Blaug, Kenyon \& Lekhi, 2007). The research focusing on job stress in correctional officers increased in 1980's (Triplett, Mullings, \& Scarborough, 1996). Dowden (2004) found that a specific correctional officer problem is perceived dangerous, role difficulties generated by the strongest predictive relation with job stress. Stress is basically required by each individual within reasonable limits because these conditions can increase a person's motivation to work and face the challenges that exist. However, if stress is raised beyond reasonable then it will have an impact or effect of its own on someone who experiences it (Ivanevich, Konopaske \& Matteson, 2005). Selye (Dacey \& Fiore,2000) distinguished two types of stress namely eustress and distress. This impact will carry on the work situation and job stress for the individuals concerned. Stress is the response of one's work, both physically and psychologically against a work environment that is caused by an imbalance between workload and the ability to finish the job (Aamodt, 2010; Riggio, 2003; Stranks, 2005). Triplett, Mullings, \& Scarborough (1996) found three resources of stress identified as having significant impact on job stress, safety concern, career development and qualitative role overload

Finney, et.al (2013) found that stressful conditions can cause high rates of turnover, high absenteeism, low productivity, decreased life satisfaction, and conflict between family and work. The negative impact of stress expressed by Finn (2000) is that stress can cause serious problems in the correctional officers. Stress can lead to boredom, stress can cause physical pain of heart disorders and eating disorders, stress on correctional officers can also cause damage to family relationships by shifting their frustration to family members and couples.

Male officers resent the presence of women in male's prisons for women are seen as having limited physical strength in responding to emergencies and less reliable in the face of dangerous prisoners or physically threatening (Zupan, 1986). The earliest finding of genderstress hypothesis to correctional officers concluded that women experience more job stress than men did, and it is in contrary with the reviews of their counterparts (Cullen et al., 1985; Wright \& Saylor, 1991; Zupan, 1986). More studies of correctional officers in prison, however, have concluded that gender-stress link is more elusive than earlier findings suggested that stress not vary by gender (Triplett, Mullings, \& Scarborough, 1996). The research results show that race, gender, and age do not contribute significantly to work related stress, given contradictory finding with other research. This condition is particularly interesting to study in Indonesia.

However, most of the women who have low wage also have family in addition to the high turnover caused by the reason of rising their children (Gilbert \& Rader, 2001). Other 
problems faced by working women are based on gender, penalty due to rising children, also sexual abuse (Benokaitis, 2001). Frequently women face conflict in their family to keep working and involve; raising more children. Gender study by Steil (Gilbert \& Rader, 2001) explained that there was perception that working women should take care of children and do household beside the fact that they work, while men do not do as much.

Generally, job stress has been characterized within the literatures on correctional officers regarding individual response to strain within the work environment (Armstrong \&Griffin, 2004). Several studies have found a link between stress and various variables such as personal characteristics and work environment. Previous research has provided evidence that is inconsistent about the effect of demographic variables such as age, race, and level of education on job stress. Brodsky (1982) found the source of stress comes not only from the individual characteristics of the employees, but also should be seen as part of the structure and culture of prisons and its role in American society. Studies have assessed the effect of several factors contributing to the level of stress among correctional officers, the officer's perception of the policies and institutional practices, interaction with colleagues and officers prisoner, officer and concerns regarding the overlap between work and family responsibilities. This study aims to prove the gender associated with prisons. Previous research has found that a prison environment provides different stress levels between men and women related to their role as correctional officers. Several studies have found that women correctional officers have higher work stress levels (Mitchell et al, 2000; Zupan, 1986). In a study Wright and Saylor (1991), reported that correctional officers women have higher levels of work stress than male officers, but the magnitude of the difference was small. Another study observed no significant association between gender and job stress (Griffin, 2001; Triplett, Mullings, \& Scarborough, 1996). Other researchers have found that gender is not a strong predictor of stress among correctional officers (Daemon \& Halemba, 1984; Lancefield, Lennings, \& Thomas, 1997). Carlson, Anson, and Thomas (2003) found that women correctional officers have better performance but less able to provide evidence of the link between gender and stress. Dowden and Teller (2004) conducted a meta-analysis of job stress correctional officers, but failed to find evidence that gender was a significant predictor of stress among correctional officers. Based on the above exposure, this study aims to find the relationship between gender and job stress in the correctional officers in Indonesian setting

\section{Method}

In this research, a survey was used to investigate the differences of job stress level between male and female correctional officers in three prisons in Bandung and Semarang Indonesia. Of ninety five participants in this study, 41 came from Bandung Female Prison, 20 came from Semarang Female Prison, 34 came from Semarang Male Prison. The sampling method that was used in this study was convenience sampling technique.

The measurement instrument used in this study used job stress scale based on Cooper \& Alison (1995). Job stress scale is used to see how high job stress experienced based on the indicators or symptoms of occupational stress, namely physical symptoms and behavioral symptoms. Job stress scale consists of 31-item with $\alpha=0.905$. 


\section{Result}

Based on the research that has been conducted, descriptive statistics are presented in table 1 below. It can be seen that job stress mean at male subjects is 57.75 , while mean of job stress at female subjects is 61.88. The hypothesis testing used one-way ANOVA. This analysis was used to see the difference in the level of job stress in the correctional officer group of men and women. From the data analysis, it shows that $F=7399, p=0.008(P<0.05)$. This study shows that gender variable has effect on job stress in which women correctional officers have higher job stress level than male correctional officers.

Table 1

The level of job stress based on gender of respondent

\begin{tabular}{lllllll}
\hline Gender & $\mathrm{N}$ & Mean & SD & df & F & p \\
\hline Male & 43 & 56.72 & 10.306 & 1 & 7.399 & .008 \\
Female & 52 & 61.88 & 8.198 & & & \\
\hline
\end{tabular}

\section{Discussion}

The theories, different exposure of stress, and hypotheses state that women experience more stress in their lives than men (Bennet, 2006). This causes women more prone and venerable to stress and psychological tension than men. Women bear more burden, difficulties and hardship in the workplace and in their family than men (Rieker\& Bird, 2000). In addition, they encounter more role strain and spillover between the demands of work and home. Even after they work fulltime, women tend to do more work in their homes than their partners.

However, most of women who also have family have a low wage, beside the high turnover caused by the reason of rising their children (Gilbert \& Rader, 2001). Other problems faced by working women based on gender are, penalty due to children rising, also sexual abuse (Benokaitis, 2001).

Women often face conflict in their family to keep working and involve more in raising children. The gender study by Steil (Gilbert \& Rader, 2001) explained that there was a perception that working women should take care of their children and do household works beside the fact that they are working, while men don't do as much.

Moreover, for dual-earner couples, it seems fair enough that socially women should be more supportive and emphasize even more to their spouse's success than themselves. Benokraitis (2011) said that the biggest reason of women worker to quit their jobs is to get back to their traditional roles and to choose to be dominant in raising their children because of the hardship in managing time between work and family. The different social roles between man and woman more or less affect women's demand in deciding whether to work or not. Men are required to be more dominant and assertive, while women are required to be warmer, 
emotionally expressive, and involve more in raising children (Miller \& Perlman, 2009).In the case of single mother, the conflict is more complex. They cannot keep staying at home because no financial support for their family however they do not receive fair treatments as men do, they do not have time to take care of their children, do not have a high wage and no children allowance (Bucks, in Benokraitis, 2011).

\section{Conclusion}

The study identified that gender has significant effect on job stress among the correctional officers in three prisons in Java Indonesia. Female correctional officers have higher job stress level than male correctional officers. These findings recommend several actions to prevent and reduce unacceptable level of job stress among correctional officers in prisons. First, stress management seminars and training should be organized to develop coping skill for correctional officers and to increase their capability to manage stressful working situation in efficient and effective ways. Second, prisons should provide health care centers that give assistance and intervention for correctional officers with higher indication of distress. Third, the human resource department in prisons should continually organize stress assessment programs for the identification and evaluation about the current level of stress and stressors that maybe experienced by their correctional officers, so the assessment data could be the foundation for implementing prevention or intervention actions to reduce stress in workplace.

\section{References}

Aamodt, M. G. (2010). Industrial/organizational psychology: An applied approach 6th edition. Belmont: Wadsworth.

Armstrong, G. S., \& Griffin, M. L. (2004). Does the job matter? Comparing correlates of stress among treatment and correctional staff in prisons. Journal of Criminal Justice, 32, 577-592.

Benokraitis, N.V. (2011). Marriages and families. Upper Sadle River, NJ: Prentice Hall.

Blaug, R., Kenyon, A., \& Lekhi, R. (2007). Stress at work: A report prepared for the work foundation's principal partners. London: The Work Foundation.

Brodsky, C. M. (1982).Work stress in correctional institutions. Journal of Prison and Jail Health, 2, 74-102.

Carlson, J. R., Anson, R. H., \& Thomas, G. (2003). Correctional officer burnout and stress: Does gender matter? The Prison Journal, 83, 277-288.

Cooper, C., \& Alison, S. (1995). Stress management. Jakarta: Kesain Blanch.

Cullen, F. T., Link, B. G.,Wolfe, N. T., \& Frank, J. (1985). The social dimensions of correctional stress. JusticeQuarterly, 2, 505-533.

Dacey, J. S., \& Fiore, L.B. (2000). Your anxious child. San Fransisco: Jossey Bass Publisher. 
Dowden, C., \& Tellier, C. (2004). Predicting work-related stress in correctional officers: A meta-analysis.Journal of Criminal Justice, 32, 31-47.

Finney, C., Stergiopoulos, E., Hensel, J., Bonato, S., \& Dewa, C.,S. (2013). Organizational stressors associated with job stress and burnout in correctional officers: a systematic review. BMC Public Health 2013, 13:82 http://www.biomedcentral.com/1471-2458/13/82.

Finn, P. (2000). Addressing correctional officer stress: Program and strategies. https://www.ncjrs.gov/pdffiles1/nij/183474.pdf.

Gilbert, L. A., \& Rader, J. (2001). Current perspective on woman's adult roles: Work, family, and life. In R.K Unger (Ed). Handbook of the Psychology of Women and Gender (pp. 156-169). NY: John Wiley.

Griffin, M. L. (2001). The use of force by detention officers. New York: LFB Scholarly Publishing.

Ivancevich, J.M., Kenopaske, R., \& Matteson, M.T. (2005). Organizational behavior and management. Boston: McGraw-Hill.

Jurik, N. C., \& Halemba, G. J. (1984). Gender, working conditions and the job satisfaction of women in a nontraditional occupation: Female correctional officers in men's prisons. Sociological Quarterly, 25,551-556.

Lancefield, K., Lennings, C. J., \& Thomas, D. (1997). Management style and its effect on prison officers' stress. International Journal of Stress Management, 4, 205-219.

Miller, R., \& Perlman, D. (2009). Intimate relationship. Boston: McGraw-hill.

Mitchell, O., MacKenzie, D. L., Styve, G. J., \& Gover, A. R. (2000). The impact of individual, organizational, and environmental attributes on voluntary turnover among juvenile correctional staff members. Justice Quarterly, 17, 333-358.

Riggio, R. E. (2003). Introduction to industrial/organizational psychology. New Jersey Inc.

Stranks, J. (2005). Stress at Work, management and prevention. Burlington: Elsevier.

Sudaryono, L. (2013). Overcrowding crisis. http://www.insideindonesia.org/currentedition/overcrowding-crisis.

Schaufeli, W.B \& Peeters, M.C.W. (2000). Job stress and burnout among correctional officers: A literature review. International Journal of Stress Management, 7(1), 43-59. 
Triplett, R., Mullings, J. L., \& Scarborough, K. E. (1996). Work-related stress and coping among correctional officers: Implications from organizational literature. Journal of Criminal Justice, 24, 291-308.

Wright, K., \& Saylor,W. (1991). Male and female employees' perceptions of prison work: Is there a difference. Justice Quarterly, 8, 505-524.

Zupan, L. (1986). Gender related differences in correctional officers' perceptions and attitudes. Journal of Criminal Justice, 14, 349-361. 